\title{
Nordisk Tidsskrift for Kriminalvidenskab
}

Marts 2021 - 108. årgang Nr. 1

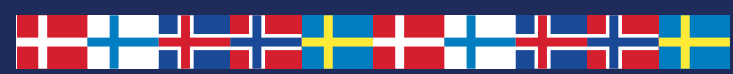

Tema:

Frihedsberøvelse og frihedsberøvede 